\title{
Hak paten sebagai objek jaminan fidusia berdasarkan peraturan perundang-undangan mengenai jaminan fidusia dan paten
}

\author{
Herda Mardiana ${ }^{1}$, Muhamad Amirulloh ${ }^{2}$, Pupung Faisal ${ }^{3}$. \\ 1 Herda Mardiana; Fakultas Hukum Universitas Padjadjaran Jl. Raya Bandung Sumedang KM-21 \\ Jatinangor; Sumedang; 45363; Indonesia; (022)84288828. \\ ${ }^{2}$ Muhamad Amirulloh; Fakultas Hukum Universitas Padjadjaran Jl. Raya Bandung Sumedang KM-21 \\ Jatinangor; Sumedang; 45363; Indonesia; (022)84288828. \\ ${ }^{3}$ Pupung Faisal; Fakultas Hukum Universitas Padjadjaran Jl. Raya Bandung Sumedang KM-21 \\ Jatinangor; Sumedang; 45363; Indonesia; (022)84288828.
}

\section{ARTICLEINFO}

Article history:

Received 2020-05-03

Received in revised form

2020-07-02

Accepted 2020-08-01

Kata kunci:

Paten; Penjaminan; Fidusia; Kredit; Perbankan.

Keywords:

Patent; Guarantees, Fiduciary;

Credit, Bank.

DOI: https://doi.org/10.26905/

idjch.v11i2.4094.

How to cite item:

Mardiana, H., Amirulloh, M., E

Faisal, P. (2020). Hak paten

sebagai objek jaminan fidusia

berdasarkan peraturan perundang-

undangan mengenai jaminan

fidusia dan paten. Jurnal

Cakrawala Hukum, 11(2)177-186.

doi:10.26905/idjch.v11i2.4094.

Corresponding Author:

* Herda Mardiana

E-mail address: mardianaherda@gmail.com

\section{Abstrak}

Dikeluarkannya peraturanbaru yang mengatur hak paten yakni Undang-Undang Nomor 13 Tahun 2016 Tentang Paten yang pada pasal 108 ayat (1) dinyatakan bahwa Hak Paten dapat dijadikan sebagai objek jaminan fidusia. Penjaminan dengan fidusia dari hak paten akan merujuk pada pengaturan dalam Undang-Undang Nomor 42 Tahun 1999 Tentang Jaminan Fidusia. Hak Paten telah sesuai dengan persyaratan yang ditentukan pada Pasal 1 butir 2 UU Jaminan Fidusia, tetapi dalam praktiknya hingga saat ini lembaga keuangan di Indonesia belum menerima hak paten sebagai objek jaminan fidusia dalam pengajuan kredit perbankan. Dalam penelitian, motode yang digunakan adalah yuridis normatif, dan spesifikasi penelitian deskriptif-analitis. Tujuannya untuk melakukan analisis terkait peraturan perundang-undangan yang berlaku dan teori hukum dengan praktik pelaksanaan dalam kenyataan. Data dikumpulkan melalui studi pustaka dan studi lapangan, kemudian dianalisis dengan metode normatif kualitatif. Hasil akhir penelitian menyatakan bahwa hingga saat ini lembaga keuangan di Indonesia belum menerima hak paten sebagai objek jaminan fidusia karena kedudukan hak peten sebagai objek jaminan fidusia belum mendapatkan kepastian hukum karena rumusan norma yang terdapat pada Pasal 108 ayat (1) UU Paten hanya bersifat mengatur dan tidak memaksa.

\section{Abstract}

The issuance of the latest law regarding patent rights is Law Number 13 Year 2016 Regarding Patents which in article 108 paragraph (1) states that Patent Rights can be used as objects of fiduciary security. Fiduciary guarantees of patents will follow the procedures set out in Law Number 42 year 1999 regarding Fiduciary Guaran- 


\section{Jurnal Cakrawala Hukum, Volume 11 No. 2 Agustus 2020 \\ ISSN PRINT 2356-4962 ISSN ONLINE 2598-6538}

tees. Patents have fulfilled the requirements specified in Article 1 point 2 of the Fiduciary Guarantee Law, but in practice until now the financial institutions in Indonesia have not received patents as objects of fiduciary collateral in filing bank loans. Normative-juridical approach methodsis used in this research, with descriptive-analytical research spesifications aimed at consideringrelation between applicable legislation and theories with the practice of implementation concerning the problems studied. Data technique used in this research is analyzed by using normative-qualitative method. The results of the study state that until now financial institutions in Indonesia have not yet received patents as fiduciary guarantees because peten rights as fiduciary guarantees have not received legal certainty because the formulation of the norms contained in Article 108 paragraph (1) of the Patent Law only regulates and does not compel.

\section{Pendahuluan}

Pembangunan ekonomi menjadi salah satu aspek pembangunan nasional. Berhasilnya pembangunan negara tercermin dari pertumbuhan perekonomian yang mampu dicapai oleh nergara tersebut. Hal tersebut juga sejalan dengan asas pembangunan nasional yang tercermin dari UndangUndang Dasar 1945 yakni Asas Kemanfaatan. Meningkatnya kegiatan pembangunan tersebut perlu ditunjang oleh pendanaan yang besar pula. Salah satu upaya yang dilakukan oleh para pelaku pembangunan adalah dengan melakukan kegiatan pinjam - meminjam atau utang - piutang. (Radinda, Mimiamanda, 2020) Umumnya, pada kegiatan pinjam meminjam perlu adanya penyerahan jaminan utang yang diberikan pihak peminjam kepada pihak yang memberi pinjaman. Jaminan utang dapat berupa barang (benda) sehingga merupakan jaminan kebendaan yang memberikan hak kebendaan dan atau berupa janji penanggung utang sehingga merupakan jaminan perorangan. (Bahsan, 2007)

Lembaga keuangan perbankan merupakan mitra bagi masyarakat dalam melaksanakan pinjammeminjam dalam bentuk kredit Pemberian kredit adalah pemberian pinjaman dana dari Bank selaku pihak kreditur pada masyarakat yang pada umumnya diperlukan adanya jaminan kredit dari pemin- jam sebagai debitur. Penerimaan atas jaminan tersebut terikat dengan ketentuan-ketentuan hukum jaminan. Seiring perkembangan zaman, Hak Kekayaan Intelektual (HKI) dapat pula digunakan untuk mendapatkan kredit perbankan dengan mengikatkan pada lembaga jaminan fidusia. Dalam praktiknya, beberapa negara lain menerima keuntungan ekonomi yang tinggi dari produk-produk HKI. (Utomo, 2010) Hal tersebut dikarenakan HKI memiliki nilai ekonomi dan dapat digunakan sebagai objek jaminan utang.

Dengan melihat ketentuan Undan-Undang Nomor 1 Tahun 2016 Tentang Penjaminan, dalam hal perkreditan perbankan, setidaknya seharusnya ada 3 (tiga) pihak didalamnya, yakni penjamin sebagai pihak yang melakukan penjaminan, penerima jaminan sebagai pihak yang memberikan kredit, serta terjamin sebagai pihak yang mendapatkan kredit.

Hak paten termasuk kedalam HKI yang dapat dijadikan sebagai objek jaminan untuk mendapatkan kredit perbankan. Dasar hukum dijadikannya hak paten sebagai objek jaminan fidusia terlihat dari Pasal 108 ayat (1) UU Paten yang menyatakan bahwa, "Hak atas Paten dapat dijadikan sebagai objek jaminan fidusia". Kemudian Pasal 108 ayat (2) menjadi pasal penunjuk untuk dibuatnya peraturan turunan yang menyatakan 


\section{Hakpaten sebagaiobjekjaminan fidusia berdasarkan peraturan perundang-undangan mengenaijaminan fidusia dan paten}

Herda Mardiana, Muhamad Amirulloh, Pupung Faisal

bahwa, "Ketentuan mengenai syarat dan tata cara hak atas Paten sebagai objek jaminan fidusia diatur dengan Peraturan Pemerintah".

Jaminan benda bergerak yang tidak berwujud seperti Saham atau Obligasi Negara dalam praktiknya sudah banyak dilakukan, namun dalam praktiknya di Indonesia, masih banyak Bank Umum Nasional maupun Bank Swasta yang belum mengimplementasikan praktik pinjaman kredit perbankan dengan Hak Kekayaan Intelektuah (HKI) khusus nya hak paten sebagai objek jaminan fidusia. Alasan penolakan perbankan adalah karena banyaknya kesulitan dalam pelaksanaannya. Salah satunya dalam hal pengikatan yang dilakukan bank terhadap hak paten yang menjadi objek jaminan fidusia belum diatur secara eksplisit, serta kendala dalam melakukan valuasi hak paten sebagai objek jaminan fidusia.

Walaupun Pasal 108 ayat (1) UU Paten sudah mengatur mengenai hak paten dapat dijadikan objek jaminan fidusia, namun hingga saat ini belum ada peraturan teknis dibawahnya berupa Peraturan Pemerintah, Peraturan Bank Indoneisa maupun Peraturan Otoritas Jasa Keuangan (POJK) yang mengatur mengenai syarat dan tata cara hak atas paten sebagai objek jaminan fidusia. Selain itu juga, saat ini belum ada apprisal yang kompeten dan diakui untuk menilai Hak Kekayaan Intelektual (HKI) tersebut.

Dengan demikian hal ini tentu sangat penting untuk dibahas dan diteliti lebih lanjut, karena dampaknya yang cukup besar bagi keberlangsungan pembangunan ekonomi di Indonesia dan kepastian hukum bagi para pemegang hak paten maupun lembaga keuangan.

\section{Metode}

Penelitian ini adalah penelitian yuridis normatif (Soedjono Soekanto dan Sri Mamudji, 1944) dengan menggunakan bahan pustaka yang terdiri dari: (1) Norma dan kaidah, peraturan dasar, serta peraturan perundang-undangan sebagai bahan hukum primer; dan (2) Bahan hukum yang memberi penjelasan terhadap bahan hukum primer seperti pendapat ahli, buku-buku atau karya ilmiah lain yang ditulis oleh ahli hukum, serta hasil karya ilmiah beberapa sarjana sebagai bahan hukum sekunder. Pengambilan data dilakukan dengan studi pustaka dari buku, jurnal ilmiah, hasil dari penelitian serta peraturan perundang-undangan terkait, juga dengan melakukan penelitian lapangan melalui wawancara dan pengamatan langsung dengan narasumber. Dalam menjawab rumusan masalah dalam penelitian, analisis data dilakukan dengan cara deskriptif kualitatif.

\section{Pembahasan}

\subsection{Kepastian hukum tentang kedudukan hak paten sebagai objek jaminan fidusia berdasarkan uu paten dan uu jaminan fidusia}

Menurut Pasal 59 UU Paten, Hak Paten adalah bagian dari HKI yang merupakan benda bergerak yang tidak berwujud. Menurut Mahardi, hak kekayaan intelektual merupakan hak kebendaan, hak atas sesuatu yang bersumber dari hasil kerja rasio manusia yang menalar berupa benda immateril. (Mahadi, 1985) Dengan dikategorikannya hak paten menjadi benda bergerak tidak berwujud, maka akan melekat terhadapnya hak-hak kebendaan. Menurut asas droit de suite, hak kebendaan yang dimiliki seseorang akan mengikuti kemanapun beda itu berada. (Amirulloh, 2016)

Hak Paten memiliki hak eksklusif yang diberikan oleh negara kepada pemilik hak paten atas hasil invensinya di bidang teknologi. Hak eksklusif tersebut baru diberikan kepada pemilik paten ketika paten tersebut sudah memenuhi persyaratan patentabilitasnya, yakni baru, mengandung langkah invenetif, serta dapat diterapkan dalam industri, kemudian didaftarkan ke Direktorat Jenderal Kekayaan Intelektual (DJKI). 


\section{Jurnal Cakrawala Hukum, Volume 11 No. 2 Agustus 2020}

ISSN PRINT 2356-4962 ISSN ONLINE 2598-6538

Hak eksklusif yang terdapat dalam paten terbagi menjadi Hak ekonomi dan Hak moral. Hak ekonomi (economic right) adalah hak untuk memperoleh keuntungan ekonomi atas kekayaan intelektual. Adanya hak ekonomi yang melekat pada hak paten membawa konsekuensi hak paten tersebut menjadi dapat dialihkan. Salah satu keuntungan dari adanya hak ekonomi dalam paten adalah hak paten tersebut dapat dijadikan sebagai objek jaminan dengan melakukan pengikatan hak paten tersebut kepada lembaga jaminan fidusia.

Jaminan Fidusia merupakan hak jaminan atas benda bergerak baik yang berwujud maupun tidak berwujud. Hak kebendaan yang terdapat dalam jaminan fidusia muncul pada tanggal jaminan fidusia tersebut dicatatkan pada buku daftar fidusia. Oleh karena itu, asas droit de suite baru berlaku sejak tanggal pencatatan jaminan fidusia tersebut. Dengan melihat ketentuan dalam UU Jaminan Fidusia tersebut, maka hak paten pada dasarnya termasuk kedalam benda yang dimaksud dalam UU tersebut sebagai salah satu benda bergerak tidak bewujud yang terdaftar dan memiliki hak kebendaan. Ketentuan lain terdapat dalam Pasal 108 ayat (1) UU Paten yang menyatakan bahwa hak atas paten dapat dijadikan sebagai objek jaminan fidusia.

Sesuai dengan ketentuan pada Pasal 4 UU Jaminan Fidusia, jaminan fidusia adalah perjanjian ikutan dari suatu perjanjian pokok. Perjanjian ikutan yang dimaksud dalam pasal tersebut dikenal juga dengan perjanjian tambahan atau accesoir. Perjanjian pokok merupakan perjanjian yang utama, sedangkan perjanjian accesoir hanya berupa perjanjian tambahan. Dalam kegiatan kredit, perjanjian pokok adalah perjanjian kredit, sedangkan perjanjian accesoir adalah perjanjian yang bersifat tambahan dan dikaitkan dengan perjanjian pokok. Hal tersebut yang menjadikan sifat perjanjian fidusia adalah accesoir yang mengikuti perjanjian pokoknya.

Hak atas paten harus diikat terlebih dahulu oleh lembaga jaminan fidusia sebelum hak paten tersebut dijadikan sebagai objek jaminan untuk mendapatkan kredit perbankan. Namun, dalam kenyataanya, terdapat kerancuan pada Pasal 108 (1) UU Paten yang berbunyi, "Hak atas paten dapat dijadikan sebagai objek jaminan fidusia." Kata-kata "dapat" dalam pasal tersebut menjadi multitafsir sehingga menimbulkan ketidakpastian hukum. Padahal seharusnya hukum memberikan kejelasan dan tidak multitafsir, serta dapat dilaksanakan dalam praktik.

Hans Kelsen menyatakan bahwa, hukum adalah suatu sistem norma, yakni pernyataan yang menekankan aspek "seharusnya" atau das sollen, dengan menyertakan peraturan yang memuat halhal yang seharusnya dilakukan. Undang-undang yang berisi aturan-aturan yang bersifat umum menjadi pedoman bagi masyarakat dalam melakukan perbuatannya. Adanya aturan itu dan pelaksanaan aturan tersebut seharusnya menciptakan kepastian hukum. Secara normatif, unsur kepastian hukum akan terpenuhi apabila peraturan dibuat dan diundangkan secara pasti serta mengatur secara jelas dan logis.

Pendapat lain dikemukakan oleh Gustav Radbruch yang mengatakan bahwa hukum harus mengandung 3 (tiga) nilai identitas, yaitu sebagai berikut: (Dwika, 2019)

1) Asas kepastian hukum (rechmatigheid); 2) Asas keadilan hukum (gerectigheit); 3) Asas kemanfaatan hukum (zwech matigheid atau doelmatigheid atau utility). Menurut Sudikno Mertokusumo, kepastian hukum merupakan jaminan bahwa hukum dijalankan, yang berhak menurut hukum dapat memperoleh haknya serta putusan dapat dilaksanakan. Kemudian dalam merumuskan undangundang seharusnya memenuhi persyaratan bahwa hukum harus tertulis (lex scripta), harus ditafsirkan seperti yang dibaca (lex stricta) dan tidk multitafsir (lex stricta). Dengan perumusan kata "dapat" dalam undang-undang tersebut, maka tidak memberikan kekuatan hukum yang memaksa sehingga tidak ada jaminan bahwa setiap pemegang hak paten bisa menjadikan hak paten nya sebagai objek jaminan 


\section{Hakpaten sebagaiobjekjaminan fidusia berdasarkan peraturan perundang-undangan mengenaijaminan fidusia dan paten}

Herda Mardiana, Muhamad Amirulloh, Pupung Faisal

fidusia untuk mendapatkan kredit perbankan maupun lembaga non-bank. Frasa "dapat" dalam Pasal 108 ayat (1) UU Paten, menjadikan ketentuan tersebut hanya bersifat pelengkap (aanvullend recht) dan mengatur, tidak bersifat memaksa (dwingend recht). Masalah penerapan sifat norma dalam hal ini menimbulkan masalah yang cukup signifikan dalam praktik, karena dengan sifat norma yang mengatur tersebut membuat lembaga keuangan Bank maupun non-bank menolak hak paten sebagai objek jaminan fidusia.

Seharusnya, hak paten secara tegas dinyatakan sebagai objek jaminan fidusia agar lembaga keuangan berkewajiban untuk mengakui sepenuhnya bahwa hak paten adalah objek jaminan fidusia. Di sisi lain, penegasan hak paten menjadi objek jaminan fidusia tidak serta merta menjadi mengharuskan lembaga keuangan untuk memberikan persetujuan terhadap setiap permohonan kredit dengan objek jaminan paten, karena pada dasarnya, keputusan mengenai diterima atau tidaknya permohonan kredit dengan hak paten sebagai objek jaminannya sepenuhnya menjadi kewenangan lembaga keuangan terkait yang tentunya memiliki regulasi dan kebijakannya sendiri dalam hal penerimaan atau penolakan kredit.

Pada intinya, seharusnya lembaga keuangan mengakui hak paten sebagai objek hukum, tanpa mempengaruhi perbuatan hukum yang dilakukan lembaga keuangan untuk mengabulkan permohonan kredit sebagai suatu perbuatan hukum. Untuk prosedur dan tata cara pengajuan kredit dengan hak paten sebagai jaminan fidusia, serta keputusan diterima atau tidaknya permohonan kredit tersebut sepenuhnya menjadi cakupan pengaturan dalam bidang hukum jaminan dan perbankan di Indonesia.

Dalam ilmu hukum, Hak paten jelas berkedudukan sebagai objek hukum yang berguna bagi subjek hukum dan dapat menjadi objek suatu hubungan hukum. Hak paten sebagai salah satu ben- tuk kekayaan intelektual tentu memiliki nilai kegunaan, baik bagi pemegang hak maupun bagi masyaakat pada umumnya. Bagi pemegang hak, kegunaan hak paten adalah menjadi hak eksklusif yang hanya dimiliki oleh pemegang hak paten tersebut. Hak eksklusif yang dimiliki pemegang paten tersebut berguna juga sebagai salah satu bentuk aset atau kekayaan yang bersifat immateril yang bernilai ekonomis dan bernilai moral atau hak moral. Dengan hak moral tersebut, kegunaan paten bagi pemiliknya adalah dikenal dan dikenang oleh para pengguna patennya dan masyarakat luas. Hak paten sebagai objek hukum juga dapat berguna bagi masyarakat karena masyarakat dapat memperoleh produk paten yang dapat memudahkan kegiatan sehari-hari. Sebagai objek hukum pun, seharusnya hak paten dapat dijadikan objek suatu hubungan hukum yang dalam hal ini adalah objek jaminan fidusia.

Dengan dipastikannya paten seebagai objek jaminan fidusia dan tumbuh serta berkembangnya kredit dengan hak paten sebagai jaminannya yang diberikan lembaga keuangan di Indonesia, maka akan mampu memberikan dampak positif bagi roda perekonomian Indonesia. Dengan banyaknya pemegang paten yang menjadikan hak patennya sebagai objek jaminan, maka secara tidak langsung akan memacu masyarakat untuk berinovasi dan menciptakan paten-paten baru yang memberikan manfaatbanyak bagi masyarakat luas dan dapat membantu meningkatkan perekonomian negara dengan produksi Paten yang tinggi. Hal tersebut selaras dengan teori perlindungan HKI yang diutarakan Robert C. Sheerwood yaitu Economic Grouth Stimulus Theory yang menyatakan bahwa HKI adalah alat bagi pengembangan ekonomi. Pengembangan ekonomi merupakan keseluruhan tujuan dibangunnya suatu sistem perlindungan HKI yang efektif. (Mahardhita, 2018)

Selanjutnya, pada Pasal 108 ayat (2) UU Paten yang menyatakan bahwa, "Ketentuan mengenai syarat dan tata cara hak atas Paten sebaga objek jaminan fidusia diatur dengan Peraturan Pemerintah". Pasal 
tersebut merupakan pasal penunjuk untuk dibuatnya peraturan turunan dari Pasal 108 ayat (1) UU Paten. Dalam praktiknya hingga saat ini belum ada peraturan teknis yang dibuat oleh pemerintah mengenai persyaratan dan tata cara hak paten sebagai objek jaminan fidusia. Oleh sebab itu, terdapat keadaan dimana aturan yang mengatur mengenai hak paten sebagai objek jaminan fidusia menjadi tidak lengkap sehingga belum menjamin kepastian hukum akibat adanya kekosongan hukum. Hal ini lah yang menyebabkan kebingungan dalam masyarakat, baik bagi para pemegang hak paten maupun bagi lembaga-lembaga keuangan khususnya Bank mengenai aturan apa yang harus diterapkan. Dengan perkataan lain, dapat dinyatakan bahwa ketiadaan Peraturan Pemerintah yang seharusnya dibuat menurut Pasal 108 ayat (2) turut menciptakan ketidakpastian hukum.

Dalam praktiknya di Indonesia, penegakkan hukum kekayaan intelektual belum menjadi prioritas bagi pemerintah. Padahal, dari sudut pandang kekayaan intelektual, pengaturan ini sangat dibutuhkan, karena sikap penghargaan dan perlindungan yang diberikan pemerintahakan memberikan rasa aman juga dapat mewujudkan iklim yang kondusif bagi peningkatan semangat masyarakat dalam menghasilkan karya-karya inovatif lainnya.

Ketidakkonsistenan pemerintah dalam membuat peraturan pelaksana ini sangat merugikan para pemilik hak paten, karena lembaga-lembaga keuangan di Indonesia menolak pengajuan hak paten sebagai objek jaminan fidusia untuk mendapat kredit karena prinsip kehati-hatian yang diterapkan dalam perbankan. Hal tersebut juga tidak sesuai dengan teori perlindungan kekayaan intelektual yakitu reward theory yang merupakan pengakuan atas HKI yang dihasilkan oleh seseorang, sehingga ia harus diberikan penghargaan sebesar-besarnya sebagai imbalan atas upaya kreatifnya dalam menemukan atau menciptakan karya intelektualnya. (Lindsay, 2002) Seharusnya pemerintah memberikan kompensasi serta dorongan sebesar-besarnya bagi para pemilik kekayaan intelektual untuk memberi keuntungan bagi masyarakat serta membantu pertumbuhan ekonomi masyarakat.

Selain itu, adapun prinsip Alter Ego yang menyatakan bahwa inventor berada pada kedudukan tertinggi yang hak kepemilikan atas suatu ciptaannya tidak dapat diganggu gugat, secara prinsip teori ini memberikan penghargaan yang tinggi dan melekat pada pencipta atas hasil karyanya. Pencipta akan mendapatkan nilai tambah terhadap martabat dan keuntungan ekonominya apabila pencipta tersebut membuat HKI yang semakin beragam dan berkualitas yang mampu membantu mencerdaskan kehidupan bangsa pada umumnya. (Mayana, 2004)

Pengaturan tentang hak paten sebagai objek jaminan fidusia juga dapat dikaji dari regulasi negara lain sebagai perbandingan hukum. Menurut Michael Bogdan, evaluasi komparatif terhadap berbagai solusi yang berbeda-beda di berbagai negara terkait isu yang sama atau serupa, akan sangat bermanfaat untuk pembuatan draft legislasi atau pekerjaan de lege ferenda yang lainnya. (Michael Bogdan, 2010) Dalam rangka membatu merumuskan asas dan teori hukum, sekaligus dasar bagi penyusunan konsep pengaturan paten yang lebih memadai sebagai objek jaminan fidusia dalam rangka pembangunan hukum jaminan di Indonesia, perlu dilakukan perbandingan dari beberapa negara seperti misalnya di negara China, Singapura dan Amerika Serikat.

Sama seperti di negara Indonesia, di ketiga negara tersebut, hukum mengenai hak paten sebagai objek jaminan fidusia pun masih bersifat mengatur. Namun demikian, norma pengaturan di ketiga negara tersebut, terkait hak paten sebagai objek jaminan fidusia juga hanya bersifat mengatur, tidak bersifat memaksa. Namun demikian, kedudukan hak paten sebagai objek jaminan fidusia telah mendapatkan pemahaman dan pengakuan yang pasti. 


\section{Hakpaten sebagaiobjekjaminan fidusia berdasarkan peraturan perundang-undangan mengenaijaminan fidusia dan paten}

Herda Mardiana, Muhamad Amirulloh, Pupung Faisal

Pada praktiknya, kondisi tersebut telah dirasakan pula sebagai suatu hambatan dalam praktik penerimaan hak paten sebagai objek jaminan fidusia dalam pemberian kredit. Dalam mengatasi kendala tersebut, terutama negara China, menempuh strategi melalui jalur kebijakan pemerinah. Pemerintah China memberikan pinjaman kepada perusahaan pemula (start up) berbasis kekayaan intelektual, dengan melakukan kontrak kerjasama program antara The State Intellectual Property Office (SIPO), yang diganti menjadi China National Intelectual Property Administration (CNIPA) dengan beberapa Bank di China. Program tersebut mampu melibatkan 6 (enam) lembaga pinjaman di China yang memberikan pinjaman senilai Y.1.308. 000.000,00 (satu juta tiga ratus delapan ribu Yuan) atau ekuivalen dengan U\$.186.860.000,00 dalam bentuk pinjaman kepada 18 (delapan belas) perusahaan. Dampak dari kebijakan tersebut antara lain mampu mendorong penciptaan paten-paten baru sehingga mampu menempatkan China sebagai pemilik paten terbanyak di Dunia.

Menurut World Intellectual Property Organization (WIPO), pengajuan hak paten global mencapai rekor tertinggi tahun lalu, dengan negara China memimpin. Sekitar 3.100.000 aplikasi hak paten diajukan di seluruh dunia tahun lalu, meningkat untuk tahun ketujuh berturut-turut dan menandai kenaikan 8,3\% dari tahun 2015. China menerima sekitar 236.600 dari hampir 240.600 paten tambahan, yang mencakup 98\% pertumbuhan. Hingga saat ini, China semakin memimpin dalam inovasi dan branding global. Secara keseluruhan, Kantor Kekayaan Intelektual Negara China menerima 1.300.000 aplikasi paten tahun lalu. Di tempat kedua, Kantor Paten dan Merek dagang AS yang tertinggal jauh di belakang, menerima 605.571 aplikasi, diikuti oleh Jepang dengan 318.381. (Stan Abrahams, IP As Loan Collateral, 2020)

Hukum Jaminan di China yang berlaku hingga saat ini adalah Guarantee Law ofthe Republic of China 1995. Peraturan mengenai penjaminan dengan hak paten yang diatur dalam hukum jaminan China tersebut tertera pada bagian 4 sub bagian 2 Pasal 75 ayat (3) yang mengatur tentang hak jaminan Pledge of Rights, yang dimana disebutkan dalam pasal tersebut bahwa: "The following rights may be pledged:...3. Property rights in the exclusive use right of trademark, patent right and thecopyrights, which are transferable according to law; and..." Dalam terjemahannya: "Berikut hak-hak yang dapat dijaminkan dengan hak jaminan Pledge: ...3. Hak kekayaan dalam hak penggunaan eksklusif atas hak merek, hak paten dan hak cipta, yang dapat dialihkan sesuai dengan peraturan yang berlaku; dan..."

Dari ketentuan pasal diatas, maka dapat diketahui bahwa hak paten merupakan kategori hak yang dapat dijaminkan dan dapat dibebankan dengan hak jaminan berupa Pledge of Rights. Mengenai pendaftaran hak paten yang dijaminkan, kemudian diatur lebih lanjut oleh peraturan SIPO yang dikenal dengan Measures for Registration of Patent Pledge(promulgated by Order Nomor 56 of the State of Intellectual Property Office (SIPO) ofChina) dan berlaku pada tanggal 1 Oktober 2010. Setiap penjaminan dengan hak paten hanya akan berlaku hingga jangka waktu yang disebutkan dalam perjanjian jaminan. Apabila hak paten telah berakhir masa jangka waktu penjaminannya maka secara otomatis SIPO juga akan mencabut pendaftaran penjaminan hak paten tersebut dan kemudian memberitahukannya kepada para pihak. Dengan demikian, sebagaimana telah diuraikan diatas mengenai dasar hukum hak paten sebagai jaminan, maka diketahui bahwa untuk pelaksanaan penjaminan hak paten di China lebih didasarkan pada ketentuan hukum yang mengatur tentang jaminan daripada ketentuan dalam hukum paten.

Sama hal nya dengan Singapura, Bahwasanya Singapura memiliki beberapa peraturan tambahan lainnya yang khusus mengatur tentang paten namun hukum yang utama yang mengatur tentang paten dan berlaku saat ini adalah Patent Act Chapter221 (Revised Edition 2005 as amended up to the Stat- 
utes (MiscellaneousAmendments) Act 2014) atau disebut

juga "Patent Act Chapter 221". Akan tetapi kemudian terhadap penggunaan hak paten sebagai jaminan bagi perusahaan yang dilaksanakan di Singapura tentu saja tidak hanya berdasar pada ketentuan dalam Patent Act Chapter 221 tetapi juga merujuk pada peraturan terkait hak paten sebagai jaminan lainnya seperti: (i) peraturan tentang perusahaan, Companies Act Chapter 50, (ii) peraturan jaminan, Commercial Law. Kebijakan yang serupa dengan yang dilakukan oleh China, tidak dilakukan oleh negara Singapura dan Amerika karena di kedua negara tersebut praktik penerimaan paten sebagai objek jaminan fidusia sudah berjalan dengan baik.

\subsection{Tindakan hukum yang seharusnya dilakukan bank umum nasional terhadap pengajuan paten sebagai objek jaminan fidusia}

Pasal 108 (1) UU Paten dinyatakan bahwa hak atas paten dapat dijadikan sebagai objek jaminan fidusia karena sifat kebendaannya, namun dalam praktiknya, sampai saat ini, belum ada lembaga keuangan baik Bank maupun Non-Bank yang menjalankan ketentuan tersebut karena terdapat kendala dalam pelaksanaannya. Kebijakan yang dilakukan Bank tersebut berkaitan erat dengan prinsip kehati-hatian Bank dalam memberikan kredit atau pembiayaan, dalam hal ini Bank harus melakukan cara-cara yang tidak memberatkan dan merugikan nasabah maupun pihak perbankan itu sendiri. Agunan yang ideal menurut UU No. 23 Tahun 1999 tentang Bank Indonesia, adalah agunan yang memiliki kepastian hukum (aspek yuridis) yang berkualitas tinggi (aspek ekonomis) dan mudah dialihkan atau dicairkan untuk dijual ke pasar (aspek strategis) menurut penilaian lembaga yang memiliki kompetensi dalam bidang tersebut serta mudah untuk dieksekusi.
Perbankan di Indonesia, khususnya dalam hal ini Bank Umum Nasional sebaiknya menerima Paten sebagai objek jaminan fidusia dalam perkreditan. Seharusnya, Bank Umum Nasional menafsirkan Pasal 108 ayat (1) UU Paten secara positif dengan mengakui dan menerima paten sebagai objek jaminan. Hal tersebut sesuai dengan teori yang diutarakan oleh Prof. Mochtar Kusumaatmadja yakni teori hukum pembangunan yang menyatakan bahwa hukum adalah sarana pembangunan masyarakat.

Sikap Bank Umum Nasional yang menerima hak paten menjadi objek jaminan fidusia berdasarkan Pasal 108 ayat (1) akan menjadi bukti nyata bahwa Undang-Undang Paten telah dilaksanakan oleh Perbankan dalam rangka meningkatkan pembangunan melalui peningkatan perekonomian yang diwujudkan dengan adanya pembiayaan yang digunakan untuk memproduksi masal paten tersebut.

Apabila dikaitkan dengan prinsip kehatihatian Bank dalam melakukan kegiatan perbankan sebagaimana dimaksud dalam Pasal 2 UU Perbankan, salah satu kendala yang membuat Bank Umum Nasional hingga saat ini belum menerima Paten debagai objek jaminan fidusia adalah dalam menilai valuasi atau penilaian dari hak paten sebagai objek jaminan. Dalam mekanisme penilaian benda yang akan dijadikan jaminan, praktek yang selama ini lazim terjadi dilapangan, Bank menggunakan jasa Penilai Publik yang lazim disebut appraisal, sebagai pihak ketiga yang merupakan profesi penunjang di sektor keuangan. Tugas Penilai Publik adalah memberikan pertimbanganpertimbangan profesional dalam melakukan penilaian ekonomi atau valuasi atas benda yang akan dibebani lembaga jaminan. Saat ini belum ada appraisal yang kompeten dan diakui baik secara internal maupun eksternal untuk menilai Hak Kekayaan Intelektual yang salah satu diantaranya adalah Paten. 


\section{Hakpaten sebagaiobjekjaminan fidusia berdasarkan peraturan perundang-undangan mengenaijaminan fidusia dan paten \\ Herda Mardiana, Muhamad Amirulloh, Pupung Faisal}

Kendala lain adalah dalam hal resiko yang akan timbul apabila debitur cidera janji atau wanprestasi karena proses pengeksekusian objek jaminan yang sulit. Bank tidak bisa memastikan bahwa hak paten tersebut akan laku dijual dengan harga yang stabil, terutama apabila melihat kurangnya daya beli masyarakat akan kekayaan intelektual serta perlindungan terhadap hak paten di Indonesia yang masih lemah.

Dalam rangka meminimalisir kendala yang dihadapi Bank Umum Nasional, serta dalam hal tetap memperhatikan prinsip kehati-hatian Perbankan, ketentuan dalam Undang-Undang Nomor 1 Tahun 2016 tentang Penjaminan dapat diimplementasikan, yakni dengan membuat suatu lembaga yang bertugas untuk menjadi pihak ketiga sebagai penjamin dalam kegiatan pinjam meminjam antara pemegang hak paten (debitur) dan perbankan (kreditur). Lembaga yang menjadi pihak ketiga tersebut nantinya akan menjadi pihak yang menjamin pengeksekusian serta pelunasan objek jaminan yang dalah hal ini adalah hak paten apabila dalam pelaksanaan kreditnya terdapat resiko seperti kredit macet atau gagal bayar. Lembaga tersebut juga bisa menjadi appraisal yang mampu mengukur value atau nilai ekonomi yang terdapat dalam Paten yang dijadikan sebagai objek jaminan fidusia.

Bank Umum Nasional sebagai kepanjangan tangan dari pemerintah juga dapat mengikuti dan melaksanakan kebijakan pemerintah untuk menerima paten sebagai objek jaminan sekaligus memberikan pembiayaan terhadap permohonan kredit tersebut. Kebijakan-kebijakan yang dikeluarkan oleh pemerintah, tentunya akan mendorong semua pihak, baik perbankan maupun masyarakat untuk mulai menerima paten sebagai objek jaminan. Kebijakan yang dilakukan oleh pemerintah China sebagaimana disebutkan sebelumnya juga dapat dipertimbangkan oleh pemerintah Indonesia untuk melakukan kebijakan serupa. Berdasarkan pengalaman di China, kebijakan tersebut diyakini akan mampu meningkatkan kreativitas inventor dalam menghasilkan paten serta meningkatkan jumlah perolehan paten terdaftar, sehingga pada akhirnya akan mampu mendorong laju pertumbuhan ekonomi di Indonesia melalui pembukaan lapangan kerja baru terkait produksi masal paten tersebut, peningkatan penerimaan pajak, serta meningkatkan day abeli masyarakat, sesuai dengan Economic Grouth Stimulus Theory yang dikemukakan oleh Robert. C. Sherwood.

\section{Kesimpulan}

Berdasarkan analisis dan uraian di atas, terdapat dua kesimpulan. Pertama, kedudukan hak peten sebagai objek jaminan fidusia belum mendapatkan kepastian hukum karena rumusan norma yang terdapat pada Pasal 108 ayat (1) UU Paten hanya bersifat mengatur sehingga dapat menimbulkan multitafsir bahwa hak paten bukan/ tidak dapat menjadi objek jaminan fidusia. Ketidakpastian hukum tersebut juga diperparah dengan kekosongan hukum akibat belum adanya Peraturan Pemerintah sebagai peratulan pelaksana sebagaimana diamanatkan oleh Pasal 108 ayat (2) UU Paten.

Kedua, Bank Umum Nasional sebaiknya menerima hak atas Paten sebagai objek jaminan fidusia dengan menafsirkan dan menerapkan Pasal 108 ayat (1) UU Paten secara positif, yaitu mengakui kedudukan hak paten sebagai objek jaminan fidusia dengan tetap memperhatikan asas kehati-hatian pemberian kredit sebagaimana dimaksud oleh UU Perbankan, serta dengan mengupayakan adanya pihak ketiga berupa lembaga yang dibuat oleh pemerintah maupun swasta yang menjamin pengembalian kredit tersebut apabila terjadi resiko dikemudian hari seperti kredit maceet atau gagal bayar sebagaimana dimaksudkan oleh UU Penjaminan. 


\section{Daftar pustaka}

Dwika. Keadilan dari Dimensi Sistem Hukm.http:// hukum.kompasiana.com (diakses 4 Desember 2019).

https://media.neliti.com/media/publications/44160- IDmenguji-asas-droit-de-suite-dalam-jaminanfidusia.pdf (diakses 6 Februari 2020).

M. Bahsan. 2007. Hukum Jaminan dan Jaminan Kredit Perbankan Indonesia, Cet.1. Jakarta. Rajagrafindo Persada.

Mahadi. 1985. Hak Milik Immateril, Jakarta. BPHN-Bina Cipta.

Michael Bogdan. 2010. Pengantar Perbandingan Sistem Hukum, terjemahan Derta Srie Widiowatie. Bandung. Nusa Media.

Mimiamanda Radinda, F., Ningsi Massora, M., \& Fathonah, R. (2020). Praktik insider trading sebagai bentuk pelanggaran prinsip keterbukaan informasi dalam pasar modal di Indonesia. Jurnal Cakrawala Hukum, 11(1), 41-49. doi:10.26905/ idjch.v11i1.3528.

Muhamad Amirulloh et. al. 2016. Buku Ajar Hukum Kekayaan Intelektual. Cet. 1. Bandung. Unpad Press.

Muhamad Amirulloh. Prinsip-Prnsip Hukum Terkait Perlindungan Nama Orang Terkenal Sebagai Nama Domain di Indonesia. Sosiohumaniora. Vol. 18 No. 2 Juli 2016.
Permadi Gandapradja. 2004. Dasar dan Prinsip Pengawasan bank. Jakarta. Gramedia Pustaka Utama.

Ranti Fauza Mayana. 2004. Perlindungan Desain Industri di Indonesia Dalam Era Perdagangan Bebas. Jakarta. Gramedia Widia Sarana Indonesia.

Sarjana, I Made; dewi kasih, desak putu; kartika, i gusti ayu. Menguji asas droit de suite dalam jaminan fidusia. Jurnal Magister Hukum Udayana (Udayana Master Law Journal), [S.l.], v. 4, n. 3, sep. 2015. doi: https://doi.org/10.24843/JMHU.2015.v04.i03.p01.

Soedjono Soekanto dan Sri Mamudji. 1994. Penelitian Hukum Normatif: Suatu Tinjauan Singkat. Jakarta. Raja Grafindo Persada.

Stan Abrahams. IP As Loan Collateral: Another China Innovation Policy, http://www.chinahearsay.com/ another-china-innovation-policy, (diakses 12 Maret 2020).

Sudikno Mertokusumo. 2007. Mengenal Hukum Suatu Pengntar. Liberty. Yogyakarta.

Tim Lindsay et. al. 2002. Hak Kekayaan Intelektual: Suatu Pengantar. Cet. 1. Alumni. Bandung.

Tomi Suryo Utomo. 2010. Hak Kekayaan Intelektual (HKI) di Era Global: Sebuah Kajian Kontemporer. Yogyakarta. Graha Ilmu.

Yoga Mahardhita. Perlindungan Hukum Hak Kekayaan Intelektual Melalui Mekanisme "Cross Border Measure”, Jurnal Ilmiah Ilmu Hukumm QISTIE Vol. 11 No. 1 Mei 2018. 